\title{
An Assessment of the Influence of Socio-Economic Variables on Credit Accessibility by Smallholder Rice Farmers in Cameroon: A Case of the West Region of Cameroon
}

\author{
Djomo, Raoul Fani*1 ${ }^{1}$, Ndaghu, Ndonkeu Nathanel ${ }^{2}$, Ukpe, Udeme Henrietta ${ }^{3}$ \\ ${ }^{1}$ Department of Agricultural Economics. University of Agriculture, Makurdi \\ PMB 2373 Makurdi, Benue-State, Nigeria \\ ${ }^{2}$ Department of Agricultural Economics, Bayero University of Kano, Kano State, Nigeria \\ ${ }^{3}$ Department of Agricultural Economics and Extension, Federal University Wukari, PMB 1020 \\ Wukari, Taraba State, Nigeria \\ *raoulfani@gmail.com
}

\begin{abstract}
Empirical studies argued that rural development should be accompanied by agricultural credit reforms. Moreover, rural development and, in particular, farm productivity, can be influenced by credit accessibility. This Study was therefore undertaken to assess the influence of socio-economic variables on credit accessibility by smallholder rice farmers in Cameroon using binary regression. A purposive, multistage and stratified random sampling technique was used in selecting the respondents. A total of 192 small scale rice farmers were purposively selected from four (4) out of eight divisions. Data were collected using structured questionnaires and interview schedule, administered on the respondents were analyzed using binary logistic regression. The result revealed that Cox\&Snell ( $R$ square) is 0.69 implying that sex; age; marital status; household size; education; farming experience; size of farm; records keeping and rice varieties accounted for 69 percent of socio-economic variables influencing credit accessibility by smallholder rice farmers in Cameroon. The result further indicated that sex; marital status (divorced); household size; education (tertiary) and rice varieties were the socio economic variables that significantly influence credit accessibility by smallholder rice farmers in the West Region of Cameroon. However, the coefficients for age marital status (married and single); education (primary and secondary); farming experience; size of farm and records keeping were not significant implying that these socio economic variables have no influence on credit accessibility by smallholder rice farmers in Cameroon. It was recommended that information on credit accessibility should be directed towards gender in order to encourage female farmers as well as credit institutions should give appropriate consideration to policy conditions as more favourable terms, collateral security and interest rate during their policy formulation.
\end{abstract}

Keywords: Assessment, Credit accessibility, Smallholder farmers, Cameroon

\section{INTRODUCTION}

Small-scale investments are reputed to be behind most of the socio-economic transformation of many economies. They play a significant role in development especially in the third world countries and generate wide-spread economic benefits (Messah, 2011). It is frequently argued in economic studies that rural development should be accompanied by agricultural credit reforms. After the financial structural adjustment of the 1980s which adversely affected the intricate system of public agencies that provide farmers with access to land, credit, insurance, and inputs, farmer organizations in developing countries started demanding an institutional reconstruction of parts of the agriculture support system such as rural development banks (World Bank, 2007, Reyes et al. 2012). Rural development and, in particular, farm productivity, can be influenced by several factors; one is access to credit. Access to credit may affect farm productivity because farmers facing binding capital constraints would tend to use lower levels of inputs in their production activities compared to those not constrained (Feder et al. 1989; Petrick, 2004; Reyes et al. 2012). Commercial banks and other formal institutions fail to cater for the credit needs of smallholders, however, mainly due to their lending terms and conditions. It is generally the rules and regulations of the formal financial institutions that have created the myth that the poor are not bankable, and since they can't afford the required collateral, they are considered not creditworthy (Atieno, 2001). Eboh (1996), Odoemenem et al. (2005) and Ocholi et al. (2012) observed that credit financed investments, help the rural poor to 
produce for the market, generate cash surpluses and accumulate savings, which will be the basis for future income growth or a protection against sudden reversals in household income and food security. Ocholi et al. (2012) also pointed out the importance of credit for stimulating agricultural production, particularly at the small-scale level with enormous unrealized production potentials. Agricultural credit in this respect is regarded as a vital component in the agricultural supporting services to be guaranteed from agro-service system. Credit cannot be over-emphasized. Therefore, this study intends to assess the influence of socio-economic variables on credit accessibility by smallholder rice farmers in Cameroon: A case of West Region of Cameroon.

Objective: the main objective of this study is to assess the influence of socio-economic variables on credit accessibility by smallholder rice farmers in Cameroon: A case of West Region of Cameroon.

\section{STATEMENT OF HYPOTHESIS}

$\mathrm{Ho}_{1}$ : Socio-economic variables have no significant influence on credit accessibility

\section{Methodology}

\subsection{The Study Area}

The study was conducted in the West Region of Cameroon which has eight divisions namely: Bamboutos, Haut-Nkam, Mifi, Menoua, Khoung-khi, Nde and Hauts-Plateaux. The West Region covers a total land area of $14000 \mathrm{sq} \mathrm{km}$ and is located in the West-Central part of Cameroon within latitudes $5^{\circ} 20^{\prime}$ and $7^{\circ}$ North and longitude $9^{\circ} 40^{\prime}$ and $11^{\circ} 10^{\prime}$ East of the equator (Yerima and Van, 2005).

\subsection{Population, Sampling procedure and Data Collection}

A sample of the population was taken by adopting a purposive, multistage and stratified random sampling procedure. First, four divisions were purposively selected (Bamboutos, Nde, Noun, and Menoua) based on the high concentration of rice production in those divisions. The second stage involved selection of one subdivision from each of the selected divisions namely: Tonga in Nde division, Foumbot in Noun division, Santchou in Menoua division, and Galim in Bamboutos division. In stage three one community in each of the selected subdivision was selected namely: Keneghang; Babitchoua; Baigom and Sekou. Having drawn the sampling frame of 2400 rice farmers in these communities collected from the West Regional Delegation of the Cameroon's Ministry of Agriculture and Rural Development, 8 percent of the sample frame was randomly selected in each community. Thus a total of 192 small scale rice farmers were selected for the study.

\subsection{Variable Specification/Model Specification}

\subsubsection{Binary Logistic Regression Model}

$\mathrm{Z}=\log \lfloor\mathrm{P} / 1-\mathrm{P}\rfloor=\log \mathrm{Y}=\beta_{0}+\beta_{1} \mathrm{X}_{1}+\beta_{2} \mathrm{X}_{2}+\beta_{3} \mathrm{X}_{3}+\beta_{4} \mathrm{X}_{4}+\beta_{5} \mathrm{X}_{5}+\beta_{6} \mathrm{X}_{6}+\beta_{7} \mathrm{X}_{7}+\beta_{8} \mathrm{X}_{8}+$ $\beta_{9} X_{9}+\varepsilon$

Where $\mathrm{Z}=$ Probability of having access to credit

access to credit $=1$ No access to credit $=0$

$\mathrm{P}=$ Probability of farmers having access to credit

$1-\mathrm{P}=$ Probability of farmers not having access to credit

$\beta_{1}, \beta_{2}, \beta_{3}, \beta_{4}, \beta_{5}, \beta_{6}, \beta_{7}, \beta_{8}, \beta_{9}$ are regression coefficients explaining changes in the independent variables

$\mathrm{X}_{1}=\operatorname{Sex}($ male $=1$ female $=0)$

$\mathrm{X}_{2}=$ Age (in years)

$\mathrm{X}_{3}=$ Marital status $($ married $=1$, single $=2$, divorced $=3$ )

$\mathrm{X}_{4}=$ Household size (number of members in the house)

$\mathrm{X}_{5}=$ Education $($ in years $)($ primary $=1$, secondary $=2$. Tertiary $=3$ )

$\mathrm{X}_{6}=$ Farming experience (in years) 
$\mathrm{X}_{7}=$ Size of farm (in hectares)

$\mathrm{X}_{8}=$ Records keeping $(\mathrm{yes}=1$, no $=0$ )

$\mathrm{X}_{9}=$ Rice varieties (improved $=1$, local $=0$ )

3.3.2. Wald Test (for the test of hypothesis)

$\chi_{c a l}^{2}=\sum \frac{\left(\beta_{i}\right)^{2}}{\operatorname{var}\left(\beta_{i}\right)}$

Where:

$\beta_{\mathrm{i}}=$ estimated coefficients

$\operatorname{var}\left(\beta_{\mathrm{i}}\right)=$ variance of the estimated $\beta_{\mathrm{i}}$ coefficients

\section{RESULTS AND DISCUSSION}

\subsection{Socio-Economic Variables Influencing Credit Accessibility by Smallholder Rice Farmers in Cameroon: A case study of West Region of Cameroon}

Table 1 summarized binary logistic regression estimates of socio-economic variables influencing credit accessibility by smallholder rice farmers in Cameroon which includes sex; age; marital status; household size; education; farming experience; size of farm; records keeping and rice varieties. As indicated in table 1, Cox\&Snell ( $\mathrm{R}$ square) is 0.69 implying that sex; age; marital status; household size; education; farming experience; size of farm; records keeping and rice varieties accounted for 69 percent of socio-economic variables influencing credit accessibility by smallholder rice farmers in Cameroon. The result further indicated that sex; marital status (divorced); household size; education (tertiary) and rice varieties were the socio economic variables that significantly influence credit accessibility by smallholder rice farmers in the West Region of Cameroon. Specifically, the coefficient of sex is positive and significant at 5 percent level of probability implying that being a male smallholder rice farmer is likely to increase probability of having access to credit by 3.32 . This may be due to the fact that male farmers are having more openness than their counterpart female in the study area. This result is contrary to the findings of Anyanwu (2004) who found that being female is likely to increase probability of having access to credit in Nigeria. Also, the coefficients of marital status (divorced) is positive and significant at 1 percent level of probability implying that being a divorced smallholder rice farmer is likely to increase probability of having access to credit by 9.28 . This may be explained by the fact that divorced smallholder farmers don't have family responsibility and therefore do not hesitate to apply for agricultural loans. The result further revealed that the coefficient of household size is negative and significant at 5 percent implying that number of members in the smallholder rice farmers is likely to decrease probability of having access to credit by 0.66. This may be due to the fact that the larger family is the more labour is available and thereby no need of looking for credit to backup farming activities. This result is contrary to the findings of Siyanbola (2012) who found that household size is likely to increase probability of having access to credit by poultry farmers in Nigeria. The coefficient for education (tertiary) is positive and significantly influences access to credit at 10 percent implying that having attended tertiary education is likely to increase the probability to have access to credit by 3.45 . This may be explained by the fact that education gives more insight and openness about advantages of getting credit to enhance farming activities. Also credit institution rely more on farmers that are educated. This result is in line with the findings of Vaessen (2000) who found that educated farmers are having higher probability of having access to credit in Nicaragua. Finally, the coefficient of rice varieties is positive and significantly influences access to credit at 5 percent level of probability implying that using improved rice varieties is likely to increase probability of having access to credit by 3.59 . However, the coefficients for age marital status (married and single); education (primary and secondary); farming experience; size of farm and records keeping were not significant implying that these socio economic variables have no influence on credit accessibility by smallholder rice farmers in Cameroon. 
Djomo, Raoul Fani et al.

Table1. Binary Logistic Regression Estimates of the Influence of Socio-Economic Variables on Credit Accessibility by Smallholder Rice Farmers in Cameroon

\begin{tabular}{|l|l|l|l|l|l|}
\hline Variables & Coefficients & S.E & Wald & Sig & Exp (B) \\
\hline Sex (1) & 1.202 & 0.391 & 9.44 & $0.002^{* *}$ & 3.32 \\
\hline Age & 0.11 & 0.021 & 0.25 & 0.615 & 1.01 \\
\hline Marital Status & & & 8.47 & & 0.03 \\
\hline Married (1) & -0.301 & 0.635 & 0.22 & 0.635 & 0.74 \\
\hline Single (2) & 0.730 & 0.638 & 1.30 & 0.253 & 2.07 \\
\hline Divorced (3) & 2.228 & 0.856 & 6.78 & $0.009^{* * *}$ & 9.28 \\
\hline Household size & -0.402 & 0.203 & 3.94 & $0.047^{* *}$ & 0.66 \\
\hline Education & & & 3.53 & 0.317 & \\
\hline Primary (1) & 0.381 & 0.496 & 0.59 & 0.442 & 1.46 \\
\hline Secondary (2) & 0.833 & 0.570 & 2.13 & 0.144 & 2.3 \\
\hline Tertiary (3) & 1.241 & 0.743 & 2.79 & $0.095^{*}$ & 3.45 \\
\hline Farming experience & 0.008 & 0.023 & 0.13 & 0.71 & 1.00 \\
\hline Size of farm & 0.145 & 0.152 & 0.91 & 0.34 & 1.15 \\
\hline Records keeping (1) & -0.877 & 0.565 & 2.40 & 0.121 & 0.41 \\
\hline Rice varieties (1) & 1.279 & 0.380 & 11.33 & $0.001^{* *}$ & 3.59 \\
\hline Constant & -0.94 & 0.871 & 0.012 & 0.914 & 0.91 \\
\hline log likelihood & 220.751 & & & & \\
\hline Cox\&Snell R square & 0.69 & & & & \\
\hline Nagelkerde R square & 0.74 & & & & \\
\hline Classification table & 70.8 & & & & \\
\hline
\end{tabular}

Source: Field Survey, $2014 * *$ and $* * *$ are significant at 5 and $10 \%$ respectively

\subsection{Result of Hypothesis Tested}

The result of the hypothesis is presented in table 2 as follow: Chi square tabulated $\left(\chi_{t a b}^{2}\right)$ at 5 percent level of probability is 15.50 while Chi-square calculated $\left(\chi_{\text {cal }}^{2}\right)$ is 54.22. Therefore, the null hypothesis that stipulated that Socio-economic variables have no significant influence on credit accessibility is rejected. In other words socio economic variables have significant influence on credit accessibility by smallholder rice farmers in Cameroon: A case of West Region of Cameroon.

Table2. Result of Wald test (test for hypothesis)

\begin{tabular}{|l|c|l|l|}
\hline Null Hypothesis & $\chi_{c a l}^{2}$ & $\chi_{\text {tab }(8,5 \%) .}^{2}$ & Decision \\
\hline$\beta_{\mathrm{i}}=0$ & 54.22 & 15.50 & ${\text { Reject } \mathrm{H}_{0}}^{2}$ \\
\hline
\end{tabular}

Source: field survey, 2014

\section{CONCLUSION AND RECOMMENDATIONS}

This study assessed the influence of socio economic variables on credit accessibility by smallholder rice farmers in Cameroon: A case of West Region of Cameroon. The study revealed that sex; marital status (divorced); household size; education (tertiary) and rice varieties were the socio economic variables that significantly influence credit accessibility by smallholder rice farmers in the West Region of Cameroon and it is concluded that socio-economic variables influence significantly credit accessibility by smallholder rice farmers in Cameroon: A case of West Region of Cameroon. It is therefore recommended that:

- Information on credit accessibility should be directed towards gender in order to encourage female farmers.

- Credit institutions should give appropriate consideration to policy conditions as more favourable terms, collateral security and interest rate during policy formulation.

- Training and workshop on credit accessibility should be organized in the study area in order to encourage smallholder rice farmers to participate in credit market. 


\section{REFERENCES}

Anyanwu, C.M. (2004). Microfinance institution in Nigeria, policy practice and potentials. Paper presented at the G24 workshop on constraints to growth in sub-Saharan Africa. Pretoria, South Africa 29-30 November.

Atieno R. (2001). Formal and Informal Institutions' Lending Policies and access to Credit by SmallScale Enterprises in Kenya: An Empirical Assessment. Research Paper Number 111. African Economic Research Consortium. Nairobi.

Eboh, E.C. (1996). Indigenous System of Group savings and Capital Formation among Nigerian Rural Households. Research Monograph. Washington D.C., African Development Foundation. PP.120.

Feder, G., L. J. Lau, J. Y. Lin and L. Xiaopeng (1989) Agricultural credit and farm performance in China. Journal of Comparative Economics, 13(4):508-526.

Messah, O.B. (2011). Factors that Influence the Demand for Credit for Credit Among Small-Scale Investors: a case study of Meru Central District, Kenya. Research Journal of Finance and Accounting. Vol 2(2): 1-31.

Ocholi, A., Odoemenem, I. U., and Lawal, W. L. (2012). An Analysis of The Effect of SocioEconomic Variables on Credit Needs of Farmers in Benue State Nigeria. Journal of Sustainable Development in Africa. Vol 14 (4):1-12.

Odoemenem, I.U.; Ezike, R.N.N. Alimba, J.O. (2005). Assessment of Agricultural Credit Availability to Small-scale Farmers in Benue State. Journal of Agricultural Science and Technology. Vol. 15 $(1 \& 2): 1-15$.

Petrick, M. (2004) A microeconometric analysis of credit rationing in the Polish farm sector. European Review of Agricultural Economics, 31(1):77-101.

Reyes, A., Lensink, R., Kuyvenhoven, A., and Moll, A. (2012). Impact of Access to Credit on Farm Productivity of Fruit and Vegetable Growers in Chile. Poster prepared for presentation at the International Association of Agricultural Economists (IAAE) Triennial Conference, Foz do Iguaçu, Brazil, 18-24 August, 2012.

Siyambola, A.A. (2012). Investigating the determinants of appropriate use of microcredit by poultry farmers in Western Nigeria. British Journal of Poultry sciences 1(1):1-4

Vaessen, J. (2000). Accessibility of rural credit in Northern Nicaragua: importance of networks of information and recommendation. Working paper 2000018. Faculty of economics, university of Antwerp

Yerima, B.P.K. and Van, R.E. (2005). Soils of Cameroon, distribution, genesis, characteristics, management and utilization. Edition clef, Yaoundé, pp.52-54.

\section{AUTHORS' BIOGRAPHY}

Djomo, Raoul Fani, is a $\mathrm{PhD}$ at the department of agricultural economics, Federal university of agriculture, Makurdi-Benue State and lecturer at the federal university wukari, Taraba-State, Nigeria

Ndaghu, Ndonkeu Nathanel, is a PhD student at Bayero Kano University, Kano State, Nigeria

Ukpe, Udeme Henrietta, is a $\mathrm{PhD}$ at the department of agricultural economics, Federal university of agriculture, Makurdi-Benue State. And lecturer at the Department of agricultural economics and extension, federal university wukari, Taraba-State, Nigeria 